\title{
Medical Microbiology and Diagnosis in the "Omic" Era
}

\section{Kevin M. Coombs ${ }^{1,2,3 *}$}

${ }^{1}$ Manitoba Institute of Child Health, Room 641 John Buhler Research Center University of Manitoba, Winnipeg, Canada

${ }^{2}$ Manitoba Center for Proteomics and Systems Biology, Room 799 John Buhler Research Centre University of Manitoba, Winnipeg, Canada

${ }^{3}$ Department of Medical Microbiology, Faculty of Medicine, University of Manitoba, Winnipeg, Canada

Infectious diseases remain one of the leading causes of death worldwide. According to the latest World Health Organization estimates (2008; http://apps.who.int/ghodata/?vid=10012), deaths attributable to infectious diseases, including respiratory illnesses, is the $2^{\text {nd }}$ leading cause of death, responsible for an estimated $12.2 \mathrm{M}(21.5 \%$ of a total of $55.9 \mathrm{M}$ ) deaths annually (Figure 1a), with cardiovascular diseases estimated as responsible for $30.5 \%$ of total deaths and neoplasms responsible for $13.6 \%$ of all deaths. The infectious disease burden is especially acute in developing countries. While infectious disease deaths account for less than 7\% of the total in the "developed" countries (such as American and European Countries; Figure 1b), it is the leading cause of death in less-developed areas (Figure 1c). Since infectious diseases afflict all sectors of the population, with many infections being particularly serious for neonates and children, whereas most cardiovascular diseases and neoplasms afflict the more elderly, the cumulative life-adjusted burden of infectious diseases is significantly higher, and thus infectious diseases may be argued to be the most serious health concern.

Therefore, better understanding of the basic mechanisms of pathogenesis, as well as improved and more rapid diagnosis and treatment of medically relevant microorganisms is of paramount importance. Considerable progress has been made during the past century in how a variety of bacteria, fungi and viruses replicate. The ways in which host cells and organisms respond to these infectious agents has lagged, partially because of the greater complexity of eukaryotic organisms as compared to prokaryotic and viral agents. This barrier to knowledge advancement has been mitigated, in part, by significant recent improvements in analytical instrumentation and bioinformatics, combined with more extensive, and complete, genomic information about a growing list of organisms of human interest. These advances have led to explosive growths in the amount of information garnered from genomic, proteomic and functional assays.

For example, knowledge about many eukaryotic organisms' entire gene repertoire has allowed development of micro-array-based techniques to study any given organism's "transcriptome" and how that transcriptome is altered after infection by a variety of pathogenic microorganisms [1-4]. Transcriptomic profiling has enjoyed explosive growth during the past $10-15$ years. However, less information is available about the quantitative and functional status of the host's effector proteins and how these are affected by infection. Recent advances in mass spectrometry instrumentation have allowed the application of a variety of labeling methodologies to the study of proteomic alterations. These include: 2-dimensional difference in gel electrophoresis $[5,6]$, isotope-coded affinity tags $[7,8]$, isotope-coded protein labels (ICPL; [9]), isobaric tags for relative and absolute quantization [10-12], and stable isotope labeling of amino acids in cell culture [13-16], as well as label-free methods [17-21]. Continued application of these types of methodologies will certainly expand the datasets of information about such changes. However, several daunting aspects of data analysis remain with respect to analysis of the huge datasets generated $[22,23]$. In addition, analysis of the quantitative differences often provides no clues about functional alterations. Thus, application of additional functional screens remains warranted. Examples include phosphoproteomics, since differential phosphorylation is one example of key post-translational modifications that can greatly impact proteins' functional status. Another recent application that should provide additional functional information includes activity-based protein profiling to assess the active status of various enzyme classes [24-26].

In summary, the combination of results provided by conducting complementary analyses that make use of multiple modalities such as those outlined above should provide significant new information about mechanisms of pathogenesis induced by various medically relevant pathogens, which in turn should aid their diagnosis and treatment. However, better integrated tools to analyze the wealth of information, and to put that information into more useful clinical application, remain future challenges.

\section{References}

1. Geiss GK, Salvatore M, Tumpey TM, Carter VS, Wang XY, et al. (2002) Cellular transcriptional profiling in influenza $A$ virus-infected lung epithelial cells: The role of the nonstructural NS1 protein in the evasion of the host innate defense and its potential contribution to pandemic influenza. Proc Natl Acad Sci USA 99: 10736-10741.

2. Belland RJ, Nelson DE, Virok D, Crane DD, Hogan D, et al. (2003) Transcriptome analysis of chlamydial growth during IFN-gamma-mediated persistence and reactivation. Proc Natl Acad Sci USA 100: 15971-15976.

3. Arnvig KB, Comas I, Thomson NR, Houghton J, Boshoff HI, et al. (2011) Sequence-Based Analysis Uncovers an Abundance of Non-Coding RNA in the Total Transcriptome of Mycobacterium tuberculosis. PLoS Pathog 7: e1002342.

4. Mehla R, Ayyavoo V (2012) Gene array studies in HIV-1 infection. Curr HIV/ AIDS Rep 9: 34-43.

5. Dhingra V, Li Q, Allison AB, Stallknecht DE, Fu ZF (2005) Proteomic profiling and neurodegeneration in West-Nile-virus-infected neurons. J Biomed Biotechnol: 271-279.

6. Vester D, Rapp E, Gade D, Genzel Y, Reichl U (2009) Quantitative analysis of cellular proteome alterations in human influenza A virus-infected mammalian cell lines. Proteomics 9: 3316-3327.

7. Booy AT, Haddow JD, Ohlund LB, Hardie DB, Olafson RW (2005) Application of isotope coded affinity tag (ICAT) analysis for the identification of differentially expressed proteins following infection of Atlantic salmon (Salmo salar) with infectious hematopoietic necrosis virus (IHNV) or Renibacterium salmoninarum (BKD). J Proteome Res 4: 325-334.

8. Cho SH, Goodlett D, Franzblau S (2006) ICAT-based comparative proteomic analysis of nonreplicating persistent Mycobacterium tuberculosis. Tuberculosis 86: $445-460$

*Corresponding author: Kevin M. Coombs, Department of Medical Microbiology, Faculty of Medicine, University of Manitoba, Winnipeg, Canada; E-mail: kcoombs@cc.umanitoba.ca

Received August 24, 2012; Accepted August 24, 2012; Published August 27 , 2012

Citation: Coombs KM (2012) Medical Microbiology and Diagnosis in the "Omic" Era. J Med Microb Diagn 2:e112. doi:10.4172/2161-0703.1000e112

Copyright: (๑) 2012 Coombs KM. This is an open-access article distributed under the terms of the Creative Commons Attribution License, which permits unrestricted use, distribution, and reproduction in any medium, provided the original author and source are credited. 
9. Nakatsuji T, Shi Y, Zhu W, Huang CP, Chen YR, et al. (2008) Bioengineering a humanized acne microenvironment model: Proteomics analysis of host responses to Propionibacterium acnes infection in vivo. Proteomics 8: 34063415.

10. Niu DD, Sui JJ, Zhang JH, Feng HX, Chen WN (2009) iTRAQ-coupled 2-D LC-MS/MS analysis of protein profile associated with HBV-modulated DNA methylation. Proteomics 9: 3856-3868.

11. Briolant S, Almeras L, Belghazi M, Boucomont-Chapeaublanc E, Wurtz N, et al (2010) Plasmodium falciparum proteome changes in response to doxycycline treatment. Malar J 9: 141

12. Huang XY, Stone DK, Yu F, Zeng YY, Gendelman HE (2010) Functiona Proteomic Analysis for Regulatory T Cell Surveillance of the HIV-1-Infected Macrophage. J Proteome Res 9: 6759-6773.

13. Skiba M, Mettenleiter TC, Karger A (2008) Quantitative whole-cell proteome analysis of pseudorabies virus-infected cells. J Virol 82: 9689-9699.

14. Kroeker AL, Ezzati P, Halayko AJ, Coombs KM (2012) Response of primary human airway epithelial cells to Influenza infection - A quantitative proteomic study. J Proteome Res 11: 4132-4136.

15. Shui W, Gilmore SA, Sheu L, Liu J, Keasling JD, et al. (2009) Quantitative proteomic profiling of host-pathogen interactions: the macrophage response to Mycobacterium tuberculosis lipids. J Proteome Res 8: 282-289.

16. Vogels MW, van Balkom BWM, Heck AJR, de Haan CA, Rottier PJ, et al. (2011) Quantitative proteomic identification of host factors involved in the Salmonella typhimurium infection cycle. Proteomics 11: 4477-4491.

17. Luber CA, Cox J, Lauterbach H, Fancke B, Selbach M, et al. (2010) Quantitative proteomics reveals subset-specific viral recognition in dendritic cells. Immunity 32: $279-289$
18. Ternette N, Wright C, Kramer HB, Altun M, Kessler BM (2011) Label-free quantitative proteomics reveals regulation of interferon-induced protein with tetratricopeptide repeats 3 (IFIT3) and 5 '-3 '-exoribonuclease 2 (XRN2) during respiratory syncytial virus infection. Virol J 8: 442.

19. Silvestrini F, Lasonder E, Olivieri A, Camarda G, van Schaijk B, et al. (2010) Protein export marks the early phase of gametocytogenesis of the human malaria parasite Plasmodium falciparum. Mol Cell Proteomics 9: 1437-1448.

20. de Souza GA, Fortuin S, Aguilar D, Pando RH, McEvoy CR, et al. (2010) Using a label-free proteomics method to identify differentially abundant proteins in closely related hypo- and hypervirulent clinical Mycobacterium tuberculosis Beijing isolates. Mol Cell Proteomics 9: 2414-2423.

21. Saka HA, Thompson JW, Chen YS, Kumar Y, Dubois LG, et al. (2011) Quantitative proteomics reveals metabolic and pathogenic properties of Chlamydia trachomatis developmental forms. Mol Microbiol 82: 1185-1203.

22. Cappadona S, Baker PR, Cutillas PR, Heck AJ, Van Breukelen B (2012) Current challenges in software solutions for mass spectrometry-based quantitative proteomics. Amino Acids 43: 1087-1108.

23. Gonzalez-Galarza FF, Lawless C, Hubbard SJ, Fan J, Bessant C, et al. (2012) A critical appraisal of techniques, software packages, and standards for quantitative proteomic analysis. OMICS

24. Steuber H, Hilgenfeld R (2010) Recent Advances in Targeting Viral Proteases for the Discovery of Novel Antivirals. Curr Top Med Chem 10: 323-345.

25. White MJ, Savaryn JP, Bretl DJ, He H, Penoske RM, et al. (2011) The HtrALike Serine Protease PepD Interacts with and Modulates the Mycobacterium tuberculosis 35-kDa Antigen Outer Envelope Protein. Plos One 6:e18175.

26. Heal WP, Tate EW (2012) Application of activity-based protein profiling to the study of microbial pathogenesis. Top Curr Chem 324: 115-135. a

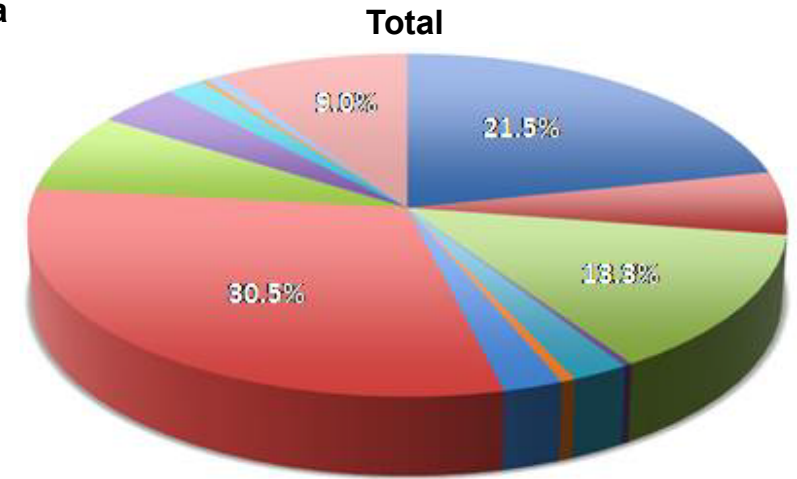

Developed Regions
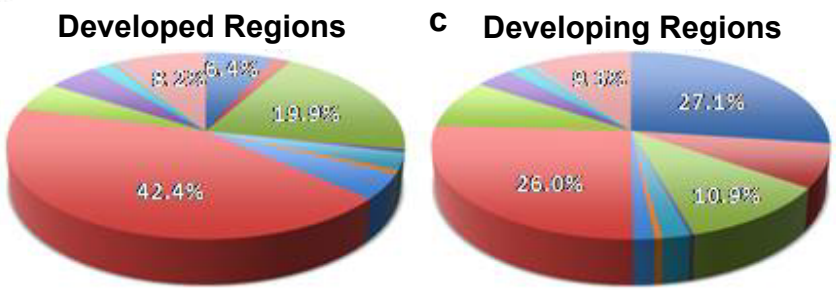

- Infections diseases \{includes respiratory\}

Maternal \& perinatal conditions and nutritional deficiencies

Malignant neoplasms

Other neoplasms

Diabetes mellitues

Nutritional/enclocrine disorders

Neuropsychiatric disorders

Cardiovascular diseases

Other respiratory diseases

Digestive diseases

Diseases of the genitorinary system

Musculoskeletal diseases

congenital abnormalities

Enjuries

Figure 1: Proportions of deaths World wide by various causes. a. Total Worldwide causes. b. Causes in Americas and Europe. C. Causes in all other regions. Data complied from http://apps.who.int/ghodata/?vid=10012. Percent values in each chart are shown only for the top 4 causes. 